\title{
ANTIOXIDANT AND ANTI-INFLAMMATORY ACTIVITIES OF RUBUS FRUTICOSUS AND ZIZYPHUS VULGARIS METHANOL EXTRACTS
}

\author{
ASMA MEZITI ${ }^{2 *}$, HAMAMA BOURICHEa , MEZITI HICHEMa, SEOUSSEN KADAa , ABDERRAHMANE SENATORa, \\ IBRAHIM DIMERTAS
}

aLaboratory of Applied Biochemistry, Department of Biochemistry, University Ferhat Abbas, Setif, Algeria, bDepartment of Chemistry, Faculty of Science, Çankırı Karatekin University, Çankırı, Turkey

Email: simsimamisa@yahoo.fr

Received: 27 Jul 2016 Revised and Accepted: 07 Dec 2016

\section{ABSTRACT}

Objective: This report is an attempt to study the phenolic composition of Rubus fruticosus (RFE) and Zizyphus vulgaris (ZVE) methanol extracts and evaluate their antioxidant and anti-inflammatory effects in-vitro and in-vivo.

Methods: Total phenolic and total flavonoids contents of extracts were determined by spectrophotometric methods. Phenolic compounds were identified by HPLC-TOF/MS. The antioxidant activities were evaluated in vitro using DPPH, ABTS and FRAP assays. The effect of RFE and ZVE on DNA cleavage induced by $\mathrm{H}_{2} \mathrm{O}_{2}$ UV-photolysis was also investigated. The antioxidant effect of RFE and ZVE was tested in vivo using the blood total antioxidant capacity test in mice. On the other hand, the anti-inflammatory activity was assessed in vivo using two models of acute inflammation ear edema and vascular permeability.

Results: The phytochemical analysis of these extracts showed that RFE possesses higher polyphenolic and flavonoid content than ZVE. in the same way RFE exerted the highest antioxidant capacity with IC 50 value of $14 \mu \mathrm{g} / \mathrm{ml}$ in DPPH assay, $1.58 \mathrm{mmol}$ of Trolox E/mg extract and 3.39 of mmol $\mathrm{FesO}_{4} / \mathrm{mg}$ extract in ABTS, and FRAP assay respectively. The studied extracts showed a concentration-dependent protective effect on DNA cleavage induced by $\mathrm{H}_{2} \mathrm{O}_{2}$ UV-photolysis. The daily oral administration of $200 \mathrm{mg} / \mathrm{kg}$ of RFE or ZVE during three weeks showed an improvement of the blood total antioxidant capacity; the $\mathrm{HT}_{50}$ values were $151.45 \mathrm{~min}$ and $146.72 \mathrm{~min}$ for the groups treated with RFE and ZVE, respectively versus 122.5 min for the control group. The topical application of $2 \mathrm{mg} /$ ear of RFE inhibited the croton oil-induced ear edema by $75.72 \%$, while the inhibition exerted by ZVE was $64.24 \%$. These inhibitions were higher than that of indomethacin, used as a reference. Moreover, the oral administration of $400 \mathrm{mg} / \mathrm{kg}$ of RFE inhibited significantly (33.57\%) acetic acid induced vascular permeability in mice. However, this effect was lower than this of indomethacin. The inhibition effect exerted by ZVE was not significant.

Conclusion: The results obtained in this investigation showed that RFE possesses strong antioxidant and anti-inflammatory potential in comparison with ZVE, which may be attributed to the presence of polyphenolic phytoconstituents.

Keywords: Antioxidant, Anti-inflammatory, Phenolic compounds, Photolysis, Hemolysis, Inflammation

(C) 2017 The Authors. Published by Innovare Academic Sciences Pvt Ltd. This is an open access article under the CC BY license (http://creativecommons.org/licenses/by/4. 0/) DOI: http://dx.doi.org/10.22159/ijpps.2017v9i2.14374

\section{INTRODUCTION}

Oxidative stress is an important factor in the genesis of several pathologies, such as cancer, cardiovascular and degenerative diseases. In order to protect the body against the consequences of oxidative stress, an efficacious approach consists in improving the antioxidant nutrition. Antioxidants from natural sources have a higher bioavailability and therefore higher protective efficacy than synthetic antioxidants [1].

Inflammation is the response of living tissues to injury. It is typically a protective mechanism that is triggered in response to noxious stimuli, trauma or infection to protect the body and to facilitate the recovery process. However, the uncontrolled response leads to chronic inflammatory disorders. A large number of steroids and non-steroidal anti-inflammatory drugs are available in the market for the treatment of inflammation. However, despite their great number, their therapeutic efficacy seems to be hampered because they are often associated with serious adverse side effects such as gastrointestinal irritation, ulcers, nephrotoxicity, and metabolic disorders [2].

It is therefore of utmost importance to search for less toxic antiinflammatory and antioxidant drugs. Medicinal plants have been documented to have an advantage in toxicity considerations based on their long term use and one might expect bioactive compounds obtained from such plants to have low animal and human toxicity [3].

It has been reported that polyphenolic compounds significantly constitute the active substances in these plants having multiple biological activities both in vitro and in vivo [4]
In Algeria, more than 600 species of medicinal and aromatic plants are employed commonly in the practice of traditional medicine, and only a few have been studied phytochemically and evaluated for their biological activity. Rubus fruticosus (Rosaceae) and Zizhyphus vulgaris (Rhamnaceae) are used in the Algerian folkl medicine for hundreds of years as antidiarrheal, anti-inflammatory, local antalgic, warmer and urinary antiseptic [5, 6].

Despite the use of these plants in traditional medicine, no or not much pharmacological and phytochemical studies are reported assessing their therapeutic properties. The aim of the present study was to investigate the phenolic profile of Rubus fruticosus and Zizyphus vulgaris methanol extracts and evaluate their antioxidant and anti-inflammatory activities in vitro and in vivo.

\section{MATERIALS AND METHODS}

\section{Materiel}

Chemicals

Indomethacin, $t$-BHP (tert-butyl hydroperoxide, Galic acid, Quercetin and Folin-Ciocalteau reagent DPPH (1,1-diphenyl-2-picryl-hydrazyl). 2,2azinobis-3-ethylbenzothiazine-6-sulfonicacid (ABTS), 2,4,6tripyridyl-s-triazine (TPTZ), ferric chloride, sodium acetate, potassium persulphate and evans blue were purchased from Sigma Aldrich (Germany). Plasmid miniprep kit was obtained from Qiagen (Valencia, CA). Xylene and croton oil were obtained from prolabo (France). All other chemicals are from Sigma and were of analytical grade. 


\section{Plant material}

Rubus fruticosus (leaves) and Zizyphus vulgaris (roots) were collected in September 2011 from Bordj Bou Arréridj, Algeria. They were identified by Pr. Houssine Laouar, University of Sétif. The voucher specimens (No R. F. 2012/57 and No Z. V. 2012/63), were deposited at the laboratory of botany in the University of Sétif Algeria. Plant material was washed, dried and powdered with an electric micronized.

\section{Animals}

Swiss albino mice are weighing 20-25 g were purchased from Pasteur Institute of Algiers, Algeria. The mice were divided into different groups each consist of 5-7 animals and were allowed to acclimatize to the animal room conditions for one week and had free access to food and water ad libitum. Animals fasted overnight prior the experiments. All procedures were performed in accordance with European Union Guidelines for Animals Experimentation (2007/ 526/EC).

\section{METHODS}

\section{Preparation of plant extracts}

One hundred grams of the powdered plant material were soaked in $80 \%$ aqueous methanol $(1 / 10, w / v)$ for $24 \mathrm{~h}$ with frequent agitation. After filtration and solvent evaporation in a rotary evaporator (Büchi) the crude methanol extracts were stored in darkness at $4{ }^{\circ} \mathrm{C}$.

\section{Determination of total phenolics}

Total phenolic content was estimated by the Folin-Ciocalteu method [7]. Two hundred microliters of diluted sample $(0.5-10 \mathrm{mg} / \mathrm{ml})$ were added to $1 \mathrm{ml}$ of $1: 10$ diluted Folin-Ciocalteu reagent. After 4 min, $800 \mu \mathrm{l}$ of saturated sodium carbonate $(75 \mathrm{~g} / \mathrm{l})$ was added. After $2 \mathrm{~h}$ of incubation at room temperature, the absorbance was measured at $765 \mathrm{~nm}$. Gallic acid $(0-160 \mu \mathrm{g} / \mathrm{ml})$ was used for the standard calibration curve. The results were expressed as milligramme gallic acid equivalent (GAE)/g extract.

\section{Determination of total flavonoids}

The total flavonoid content was determined by the aluminum chloride colorimetric method described by Bahorun et al. [8] Briefly, $1 \mathrm{ml}$ of $2 \%$ aluminium trichloride $\left(\mathrm{AlCl}_{3}\right)$ in methanol was mixed with the same volume of extracts $(0.25-0.5 \mathrm{mg} / \mathrm{ml})$, After $10 \mathrm{~min}$ of incubation at room temperature, the absorbance was measured at $430 \mathrm{~nm}$. Quercetin was used for the standard calibration curve. The data were expressed as milligram quercetin equivalents $(\mathrm{QE}) / \mathrm{g}$ extract.

\section{Analysis of phenolic compound by HPLC-TOF/MS}

Dried crude extracts $(200 \mu \mathrm{g})$ of Rubus fruticosus and Zizyphus vulgaris were dissolved in methanol at room temperature. Samples were filtered through a PTFE $(0.45 \mu \mathrm{m})$ filter by an injector to remove particulates. Injection volume was $10 \mu \mathrm{l}$. Phenolic compounds analysis was carried out as described by [9], using an Agilent Technologies 1260 Infinity HPLC System coupled with 6210 Time of Flight (TOF) LC/MS detector. The separation was carried out

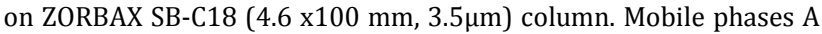
and B were ultra-pure water with $0.1 \%$ formic acid and acetonitrile, respectively. Flow rate was $0.6 \mathrm{ml} \mathrm{min}-1$ and column temperature was $35^{\circ} \mathrm{C}$. The solvent program was as follow: 0-1 min $10 \% \mathrm{~B}, 1-20$ $\min 50 \%$ B, $20-23$ min $80 \%$ B, $23-25$ min $0 \%$ B; $25-30$ min $10 \%$ B. Ionization mode of HPLC-TOF/MS instrument was negative and operated with a nitrogen gas temperature of $325{ }^{\circ} \mathrm{C}$, nitrogen gas

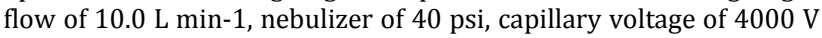
and finally, fragmentor voltage of $175 \mathrm{~V}$. Phenolic compound were identified by the retention time of sample chromatographic peaks being compared with those of authentic standards using the same HPLC operating condition and also by the extract being spiked with the standard components.

\section{DPPH radical scavenging activity}

The free radical scavenging capacity of the studied extracts was tested as bleaching of the stable 1,1 diphenyl-2-picrylhydrazyl radical (DPPH) [10]. The reaction mixture contains $1.5 \mathrm{ml}$ of DPPH solution $(100 \mathrm{mmol})$ and $37.5 \mu \mathrm{l}$ of different extracts concentration $(5-50 \mu \mathrm{g} / \mathrm{ml})$. After $20 \mathrm{~min}$ at room temperature, the absorbance was recorded at $517 \mathrm{~nm}$ and the percentage of radical scavenging activity was calculated as follow:

DPPH scavenging activity $(\%)=[($ Abs control-Abs sample $) /$ Abs control $] \mathrm{X}$ 100

Where Abs control is the absorbance of the control reaction mixture without the test compounds, and Abs sample is the absorbance of the test compounds.

\section{ABTS radical scavenging activity}

The ability of Rubus fruticosus and Zizyphus vulgaris extracts to scavenge the ABTS radical was evaluated according to Re et al. [11]. The ABTS radical cation was produced by the oxidation of $1.7 \mathrm{mmol}$ ABTS with potassium persulphate $(4.3 \mathrm{mmol})$ in water. The mixture was allowed to stand in the dark at room temperature for 12-16 h before use, and then the ABTS solution was diluted with phosphate buffered saline (PBS) at $\mathrm{pH} 7.4$ to give an absorbance of $0.7 \pm 0.02$ at $734 \mathrm{~nm}, 50 \mu \mathrm{l}$ of the methanol solution containing different concentrations of the extract $(0.03-0.5 \mathrm{mg} / \mathrm{ml})$ were added to $2 \mathrm{ml}$ of the ABTS preparation and the absorbance was recorded at 734 $\mathrm{nm}$, after allowing the reaction to stand for $6 \mathrm{~min}$ in the dark at room temperature. The unit of total antioxidant activity was defined as the concentration of trolox having the equivalent antioxidant activity, expressed as mmol trolox equivalent/mg extract.

\section{Ferric reducing/antioxidant power (FRAP)}

The ferric reducing ability of the extracts under study was evaluated according to the method described by Benzie and strain. [12] With minor modifications. The FRAP reagent contained $10 \mathrm{mmol}$ of TPTZ solution in $40 \mathrm{mmol} \mathrm{HCl}, 20 \mathrm{mmol} \mathrm{FeCl}$, and acetate buffer (300 mmol, pH 3.6) (1:1:10, v/v/v). $50 \mu \mathrm{l}$ of a methanol solution containing different concentrations $(0.03-1 \mathrm{mg} / \mathrm{ml})$ of the extracts tested or of the vehicle (methanol) alone were added to $1 \mathrm{ml}$ of the FRAP reagent. After incubation at $20^{\circ} \mathrm{C}$ for $4 \mathrm{~min}$, the absorbance was measured at $593 \mathrm{~nm}$, using the FRAP reagent as a blank. Methanol solutions of known Fe(II) concentration, ranging from 100 to $1000 \mu \mathrm{M} \mathrm{FeSO} 4$ were used for the preparation of the calibration curve and results are expressed in $\mathrm{mmol} F e($ II) $/ \mathrm{mg}$ extract.

\section{DNA oxidation induced by the photolysis of $\mathrm{H}_{2} \mathrm{O}_{2}$}

DNA damage protective activity of Rubus fruticosus and Zizyphus vulgaris extract was checked on pBluescript M13 (+) plasmid DNA. Plasmid DNA was oxidized with $\mathrm{H}_{2} \mathrm{O}_{2}+\mathrm{UV}$ treatment in the presence of Rubus fruticosus and Zizyphus vulgaris extracts and checked on $1 \%$ agarose after modification [13]. In brief, the experiments were performed in a volume of $10 \mu \mathrm{l}$ in a microcentrifuge tube containing $200 \mathrm{ng}$ of plasmid DNA in phosphate buffer (7.14 mmol phosphate and $14.29 \mathrm{mmol} \mathrm{NaCl}), \mathrm{pH} 7.4, \mathrm{H}_{2} \mathrm{O}_{2}$ was added at a final concentration of $2.5 \mathrm{mmol} / \mathrm{l}$ with and without $1 \mu \mathrm{l}$ of $(100,250,350$, $500 \mu \mathrm{g} / \mathrm{ml}$ ) Rubus fruticosus and Zizyphus vulgaris extracts. The reactions were initiated by UV irradiation and continued for $5 \mathrm{~min}$ on the surface of a UV transilluminator with intensity $8000 \mu \mathrm{W} \mathrm{cm}-1$ at $300 \mathrm{~nm}$ at room temperature. After irradiation, the reaction mixture $(10 \mu \mathrm{l})$ with gel loading dye was placed on $1 \%$ agarose gel for electrophoresis. Electrophoresis was performed at $40 \mathrm{~V}$ for $3 \mathrm{~h}$ in the presence of ethidium bromide $(10 \mathrm{mg} / \mathrm{ml})$. Untreated pBluescript M13+plasmid DNA was used as a control in each run of gel electrophoresis along with partial treatment, i.e., only UV treatment and only $\mathrm{H}_{2} \mathrm{O}_{2}$. Gels were stained with ethidium bromide and photographed with the Gel documentation system (Gel-Doc-XR, BioRad, Hercules, CA). The intensity of each DNA band was quantified by means of densitometry.

\section{Blood total antioxidant capacity}

The effect of Rubus fruticosus and Zizyphus vulgaris extracts on the total antioxidant capacity of mice were accessed according to the method described by Girard et al. [14] with slight modifications by replacing the radical AAPH [2,2-'-azo-bis azo-bis (2amidinopropane) $\mathrm{HCl}$ ] by the tert-butyl hydroperoxide (t-BHP). The Principle of the test is to submit whole blood to a thermo-controlled free radical aggression. All families of antioxidant present in the 
blood are mobilised to fight off the oxidant attack and to protect the integrity of erythrocytes resulting in the delay of hemolysis.

Two groups of mice were given orally $200 \mathrm{mg} / \mathrm{kg}$ of Rubus fruticosus or Zizyphus vulgaris extracts. The control group received the same volume of normal saline solution. After twenty-one days of daily treatment, blood (0.5-1 ml) was collected by cardiac puncture after diethylique ether anaesthesia. A subsample of whole blood $100 \mu \mathrm{l}$ was immediately diluted in $2,4 \mathrm{ml}$ of PBS ( $\mathrm{NaCl} 125 \mathrm{mmol}$, sodium phosphate $10 \mathrm{mmol}, \mathrm{pH} \mathrm{7,4)}$ and $80 \mu \mathrm{l}$ of diluted blood was deposited in an a96-well microplate with $136 \mu$ of t-BHP (166 $\mu \mathrm{M}$ in solution) and then incubated at $37^{\circ} \mathrm{C}$. The hemolysis kinetic was followed using a 96-well microplate reader (ELX 800 de Bio-TEK instruments) by measuring optical density decrease at $630 \mathrm{~nm}$. The blood resistance to free radical attack is expressed by the time needed to hemolyse $50 \%$ of the red blood cells (half-hemolysis time, $\mathrm{HT}_{50}$ in min).

\section{Croton oil-induced ear edema in mice}

To evaluate the topical effect of the studied extracts on acute inflammation, croton oil-induced ear edema was performed according to Manga et al. [15]. Cutaneous inflammation was induced to the inner surface of the right ear of mice by application of $15 \mu \mathrm{l}$ of acetone containing $80 \mu \mathrm{g}$ of croton oil as an irritant. Treated animals received topically $2 \mathrm{mg} /$ ear of extract. Indomethacin as reference drug was applied topically ( $0.5 \mathrm{mg} / \mathrm{ear}$ ). The thickness of ears was measured before and $6 \mathrm{~h}$ after induction of inflammation using a dial calliper. The edema was expressed as an increase in the ear thickness due to croton oil application.

\section{Acetic acid-induced vascular permeability in mice}

The effect of Rubus fruticosus and Zizyphus Vulgaris extracts on vascular permeability was evaluated according to the method of Kou et al. [16] with slight modifications. Mice were divided into four groups. They obtained orally $0.2 \mathrm{ml}$ of either $400 \mathrm{mg} / \mathrm{kg}$ of Rubus fruticosus or Zizyphus Vulgaris or $50 \mathrm{mg} / \mathrm{kg}$ indomethacin; the control group received the same volume $(0.2 \mathrm{ml})$ of normal saline solution. One hour later, $10 \mathrm{ml} / \mathrm{kg}$ of $1 \%$ solution of Evans Blue dissolved in normal saline solution was intravenously administrated. Then $10 \mathrm{ml} / \mathrm{kg}$ of $0.7 \%$ acetic acid was intraperitoneally injected. Thirty minutes later, mice peritoneal exudates were collected after being washed with $3 \mathrm{ml}$ of normal saline solution and centrifuged at $2000 \mathrm{rpm}$ for $10 \mathrm{~min}$. The absorbance of the supernatant was read at $610 \mathrm{~nm}$. The dye content of the exudates, which refers to the rate of vascular permeability, was calculated according to the standard curve of Evans Blue.

\section{Statistical analysis}

Data obtained in vitro and in vivo are expressed as mean \pm SD and mean \pm SEM, respectively. The hemolysis sigmoïdes were fitted by computer analysis Software Graph Pad. Prism (V5.00). Differences between the control and the treatments in these experiments were tested for significance using analysis of variance followed by Dunnet's/tukey's test. A probability of $(\mathrm{P}<0.05)$ was considered significant

\section{RESULTS AND DISCUSSION}

\section{Total phenolic and flavonoid content}

Several studies have focused on the biological activities of phenolic compounds and flavonoids, which are potential antioxidants and anti-inflammatory agent [17]. The obtained Results (table 1) showed that Rubus fruticosus extract contained higher amounts of total phenolic compounds and flavonoids than Zizyphus vulgaris extract. A very low quantity of flavonoids was observed in Zizyphus vulgaris extract.

Table 1: Polyphenols and flavonoids content of Rubus fruticosus and Zizyphus vulgaris methanol extracts

\begin{tabular}{|c|c|c|}
\hline & Phenolic compounds ( $\mu$ g GAE/mg extract) ${ }^{a}$ & Flavonoids ( $\mu \mathrm{g} Q \mathrm{QE} / \mathrm{mg}$ extract) ${ }^{\mathrm{a}}$ \\
\hline Rubus fruticosus & $227.15 \pm 46.35$ & $24.27 \pm 0.46$ \\
\hline zizyphus vulgaris & $134.62 \pm 8.06$ & $0.33 \pm 0.023$ \\
\hline
\end{tabular}

GAE: Galic Acid Equivalent; QE: Quercetine Equivalent. ( ${ }^{a}$ mean $\pm S D, n=3$ ).

\section{Identification of phenolic compound by HPLC-TOF/MS}

According to the retention time of calibration standards (table 2), Rubus fruticosus extracts presented a chemical profile (fig. 1A) composed of several phenolic compounds; nine compounds were identified as phenolic acids and eight compounds as flavonoids belonging to different classes. Scutellarin as flavone was the most flavonoid and phenolic compound followed by chlorogenic acid; quercetin-3- $\beta$-D- glucoside represented the major flavonol followed by fisetin. Hydroxybenzoic acid and kampferol can be considered as minor compounds in Rubus fruticosus extract. Zizyphus Vulgaris extract (fig. 1B) revealed the presence of only seven phenolic compounds, including four phenolic acid and three flavonoids (rutin, naringin, and catechin). In fact, Protocatechuic acid represents the major phenolic acid. catechin as flavanol represents the major flavonoid in Zizyphus Vulgaris extract.

Table 2: Phenolic compounds determined by HPLC-TOF/MS in Rubus fruticosus and Zizyphus vulgaris extracts

\begin{tabular}{|c|c|c|c|}
\hline Phenolic compound & Retention time (min) & Rubus fruticosus ( $\mu \mathrm{g} / \mathrm{mg}$ extract) & Zizyphus vulgaris ( $\mu \mathrm{g} / \mathrm{mg}$ extract) \\
\hline Gentisic acid & 4.55 & 74.46 & 93.39 \\
\hline Catechin & 6.15 & 145.34 & 932.07 \\
\hline Chlorogenic acid & 6.22 & 5918.51 & -_ \\
\hline Protocatechuic acid & 6.93 & 131.48 & 219.49 \\
\hline 4-hydroxybenzoic acid & 7.69 & 4.13 & 44.19 \\
\hline Caffeic acid & 7.70 & 420.93 & - \\
\hline Vanillic acid & 8.04 & 61.06 & 106.73 \\
\hline Syringic acid & 9.35 & 145.72 & -_ \\
\hline Rutin & 9.49 & 35.34 & 18.23 \\
\hline Ellagic acid & 9.97 & 1367.81 & -_ \\
\hline Quercetin-3- $\beta$-D-glucoside & 10.07 & 2247.62 & -_ \\
\hline Naringin & 10.63 & 53.44 & 39.41 \\
\hline Fisetin & 11.02 & 179.34 & -_ \\
\hline Scutellarin & 11.02 & 13093.34 & -_ \\
\hline Neohesperidin & 11.42 & 33.81 & - \\
\hline Cinnamic acid & 16.31 & 71.81 & - \\
\hline kaempferol & 16.84 & 13.95 & $\ldots$ \\
\hline
\end{tabular}




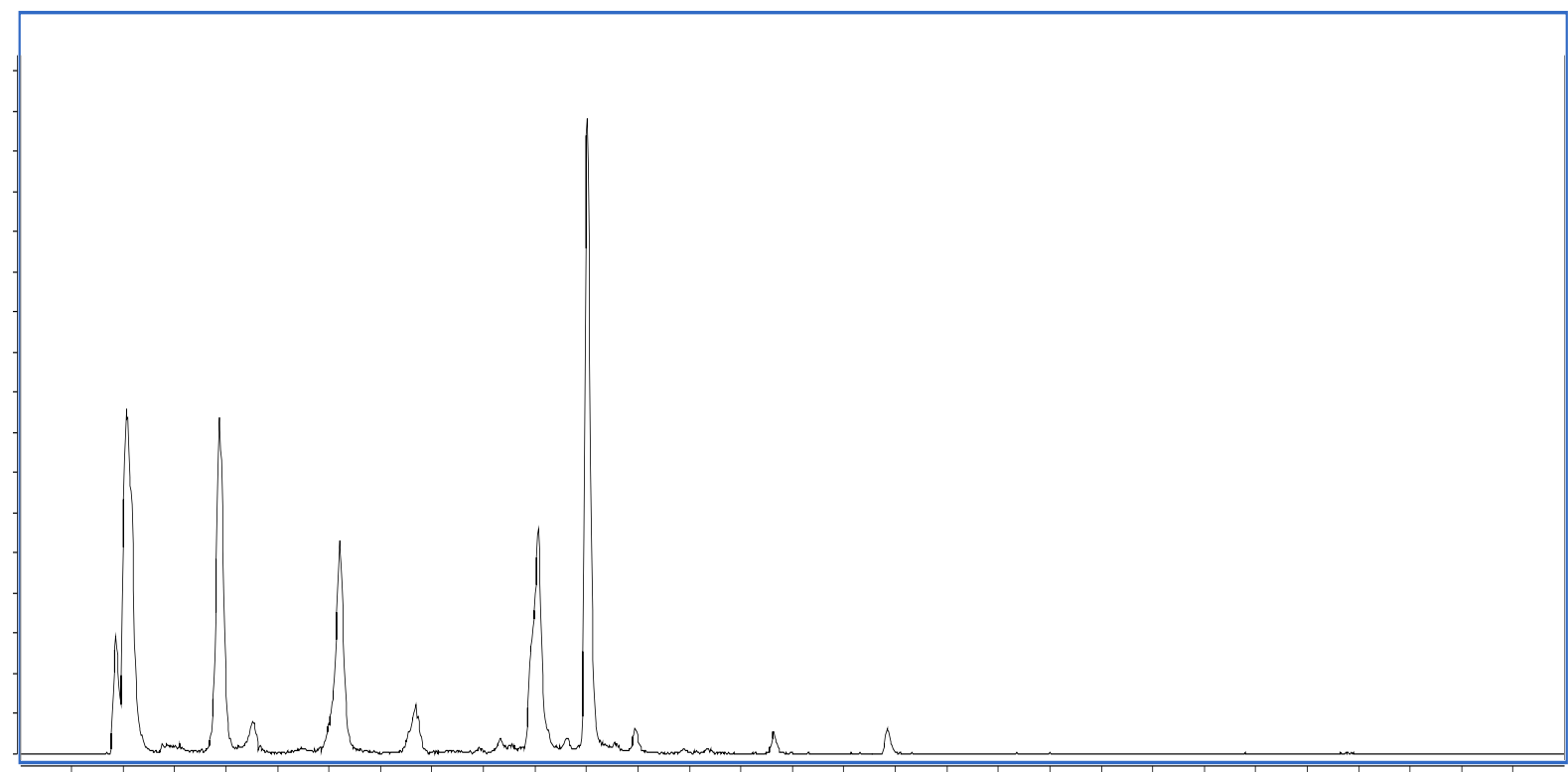

A

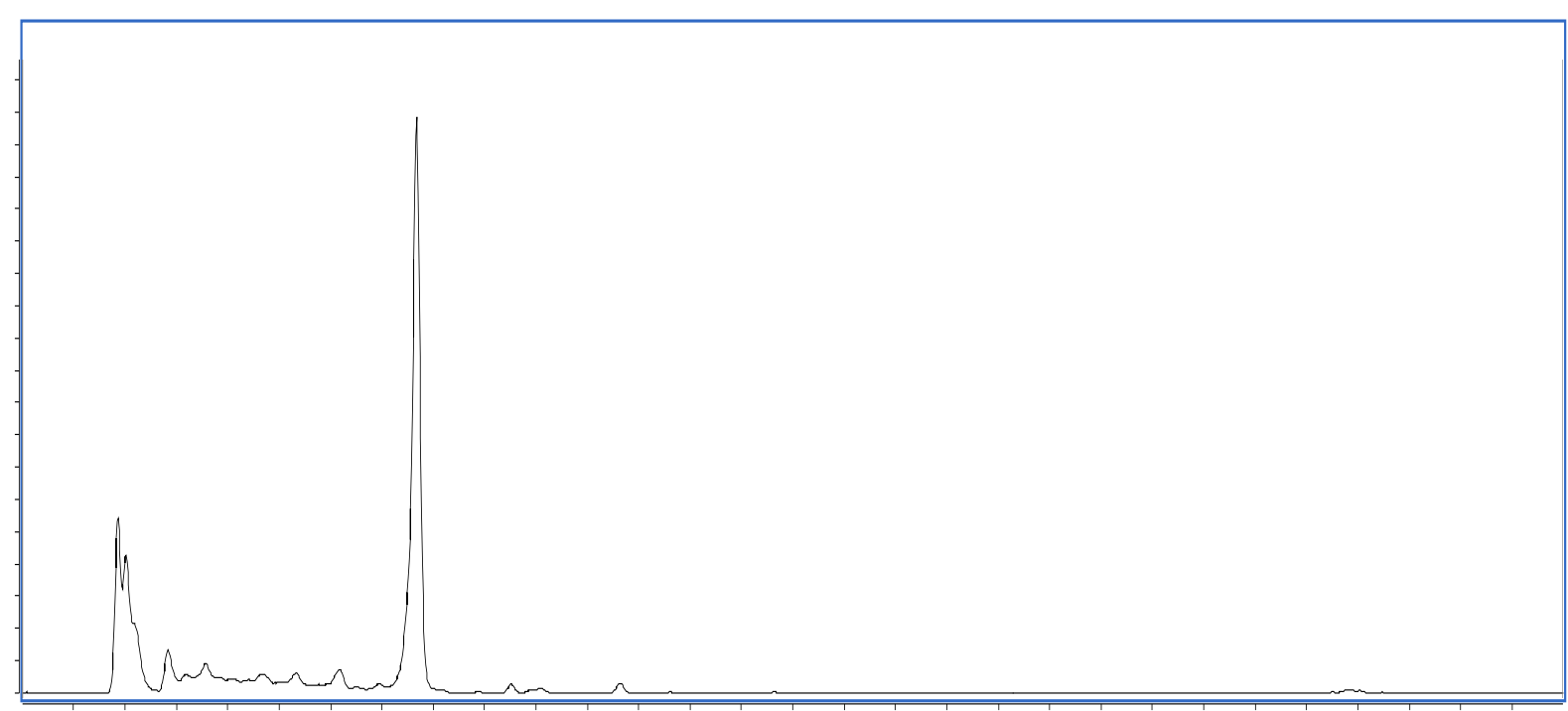

B

Fig. 1: HPLC chromatograms for Rubus fruticosus (A) and Zizyphus vulgaris (B) extracts

\section{DPPH radical scavenging activity}

The 1,1-diphenyl-2-picrylhydrazyl (DPPH) is a stable radical with a maximum absorbance at $517 \mathrm{~nm}$ that can readily undergo reduction by an antioxidant. Because of the ease and convenience of this reaction, it has now widespread use in the free radical-scavenging activity assessment [18]. Both extracts exhibited antiradical activity (fig. 2). Rubus fruticosus extract shows a high radical scavenging activity with $\mathrm{IC}_{50}$ value $(14 \mu \mathrm{g} / \mathrm{ml})$. However, Zizyphus vulgaris extract possesses the half radical scavenging activity exhibited by Rubus fruticosis extract with a value of $\mathrm{IC}_{50}(29.81 \mu \mathrm{g} / \mathrm{ml})$.

This difference of radical scavenging activity is attributed to the difference in phenolic and flavonoid content. Indeed, phenolic compounds, especially flavonoids are recognised as potentially antioxidant substances with the ability to scavenge free radical species, and reactive forms of oxygen, the scavenging effect of flavonoids(FLO) is attributed to their low potential redox making them thermodynamically able of reducing free radicals by a transfer of hydrogen from hydroxyl groups.

This reaction gives rise to aroxyl radical (FLO•) and the stabilised radical; the $(\mathrm{FLO} \bullet$ ) subsequently undergo a structural rearrangement allowing redistributing the unpaired electron on the aromatic ring and the stabilisation of aroxyl radicals [19].

\section{ABTS radical}

Due to its operational simplicity, the ABTS assay has been used in many research laboratories, to measure the total antioxidant capacity in pure substances, in body fluids, and in plant material [20, 21]

The results of antioxidant activity were expressed as Trolox equivalent antioxidant capacity (TEAC) values, as shown in table 3 .

Similarly to the DPPH assay, ABTS assay revealed that Rubus fruticosus extract exerted the highest antioxidant capacity. 

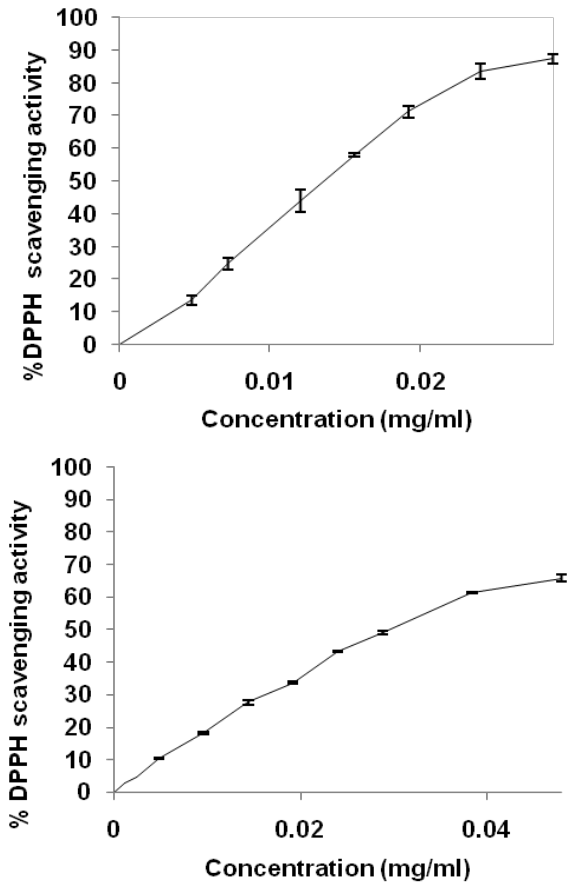

Fig. 2: DPPH radical scavenging activity of Rubus fruticosus and Zizyphus vulgaris extracts, The values are means $\pm \mathrm{SD}(\mathrm{n}=3)$

Table 3: Trolox equivalent antioxidant capacity of Rubus fruticosus and Zizyphus vulgaris extracts

\begin{tabular}{ll}
\hline & mM Trolox E/mg extract \\
\hline Rubus fruticosus & $1.58 \pm 0.22$ \\
Zizyphus vulgaris & $0.79 \pm 0.14$ \\
\hline
\end{tabular}

Trolox E: Trolox Equivalent. (amean \pm SD, $n=3$ ).

\section{Ferric reducing/antioxidant power}

Antioxidants can be explained as reductants, and inactivation of oxidants by reductants and can be described as redox reactions in which one reaction species (oxidant) is reduced at the expense of the oxidation of another antioxidant. The FRAP assay measures the antioxidant effect of any substance in the reaction medium as reducing ability [22].

The ferric reducing capacities of the studied extract are represented in table 4. Rubus fruticosus extract showed the highest antioxidant capacity as it has been recorded in Folin ciocalteu, DPPH and ABTS essays followed by Zizyphus vulgaris. These results are in agreement with previous studies [23] who found a strong relationship between phenolic contents and antioxidant activity.

Table 4: Ferric reducing the antioxidant power of Rubus fruticosus and Zizyphus vulgaris extracts.

\begin{tabular}{ll}
\hline & mM FesO $_{4} /$ mg extract $^{\mathbf{a}}$ \\
\hline Rubus fruticosus & $3.39 \pm 0.079$ \\
zizyphus vulgaris & $1.04 \pm 0.089$ \\
\hline
\end{tabular}

amean \pm SD, $n=3$.

\section{Effect of Rubus fruticosus and Zizyphus vulgaris extracts on DNA damage}

The protective effect of Rubus fruticosus and Zizyphus vulgaris on $\mathrm{H}_{2} \mathrm{O}_{2}+\mathrm{UV}$-induced DNA damage was studied on pBluescript M13 (+) plasmid DNA. Photolysis of $\mathrm{H} 2 \mathrm{O} 2$ can occur when it absorbs a significant amount of light, which can be any wavelength less than $380 \mathrm{~nm}$. This process can be described in general by the following reaction:

$$
\mathrm{H}_{2} \mathrm{O}_{2}+h v \longrightarrow 2 \cdot \mathrm{OH}
$$

Due to the formation of highly reactive and strong oxidizing hydroxyl radical, the native supercoiled configuration of plasmid DNA changes to open circular and nicked linear forms, which cause a change in their electrophoretic mobility properties on the gel [24].

Fig. 3 A shows the electrophoretic pattern of DNA in the presence or absence of $(100,250,350$ and $500 \mu \mathrm{g} / \mathrm{ml})$ of Rubus fruticosis or Zizyphus vulgaris extract. The plasmid DNA showed two bands on agarose gel electrophoresis (lane 1) the faster moving prominent band corresponded to the native supercoiled circular DNA (sc DNA) and the slower moving very faint band was the open circular form (oc DNA). The UV irradiation of DNA in the presence of $\mathrm{H}_{2} \mathrm{O}_{2}$ (lane 2) resulting the cleavage of sc DNA to give prominent oc DNA and a faint linear (Lin) DNA indicating that $\mathrm{OH}_{-}$generated from UVphotolysis of $\mathrm{H}_{2} \mathrm{O}_{2}$ produced DNA strand scission. It was noted that only UV treatment and only $\mathrm{H}_{2} \mathrm{O}_{2}$ treatment (lanes 3 and 4 , respectively) could not induce damage as noted in combined treatment (lane 2).

The addition of Rubus fruticosus or Zizyphus vulgaris extracts (lanes 6-9) to the reaction mixture suppressed the formation of lin DNA and induced a significant protection to the damage of native supercoiled circular DNA in a dose-dependent manner. In fact, the intensity of sc DNA bands (fig. 3B) scanned from the agarose gel electrophoretic patterns was 81.64, 87.18, 91.07 and $93.31 \%$ for plasmid DNA treated with $\mathrm{H}_{2} \mathrm{O}_{2}$ in the presence of $(100,250,350$ and $500 \mu \mathrm{g} / \mathrm{ml}$ ) Rubus fruticosus extract, and 59.87, 66.32, 72.45 and $69.17 \%$ in the presence of Zizyphus vulgaris extract, respectively as compared with the untreated plasmid DNA.

Hydroxyl radicals can be produced inside cells through various reactions as UV-induced decomposition of $\mathrm{H}_{2} \mathrm{O}_{2}$ used in the present study and can damage macromolecules such as lipids, proteins, and DNA, resulting in the onset of several diseases [25]. Hydroxyl radical is known to react with all components of the DNA molecule; the purine and pyrimidine bases as well as the deoxyribose backbone. It is well known that in various cancer tissues, hydroxyl radicalmediated DNA damage was observed [26].

DNA damage protecting the activity of Rubus fruticosus and Zizyphus vulgaris extract is corresponding to their antioxidant potential. These extracts might, therefore, be used to prevent cancer. Thus, the identification of natural products able to provide protection against UV radiation-induced inflammatory responses and the generation of oxidative stress may have important human health implications.

\section{Blood total antioxidant capacity}

The effect of the treatment with Rubus fruticosus and Zizyphus vulgaris extracts on the total antioxidant status of mice was evaluated using an assay based on the whole blood resistance to free radical aggression, taking into account all the body reserves since blood contains every kind of enzymatic and molecular antioxidant [27]. These antioxidants are mobilised during a radical attack induced ex vivo by t-BHP, to protect erythrocytes integrity and then delay their hemolysis.

From the obtained sigmoid hemolysis curves (fig. 4), it appears that treatment with Rubus fruticosus and Zizyphus vulgaris extracts caused a delay of hemolysis which is evident in a shift of the curves to the right. The calculated $\mathrm{HT}_{50}$ values (fig. 5) reveal an extension of half hemolysis time in the two treated groups compared with controls. For the group treated with Zizyphus vulgaris extracts, the increase in half-hemolysis time (HT50=146.72 $\mathrm{min}$ ) is statistically no significant compared with the control group (HT50=122.5 min). However, in the group treated with Rubus fruticosus the delay of hemolysis is more important and statistically significant $\left(\mathrm{HT}_{50}=151.45 \mathrm{~min}\right)$. 

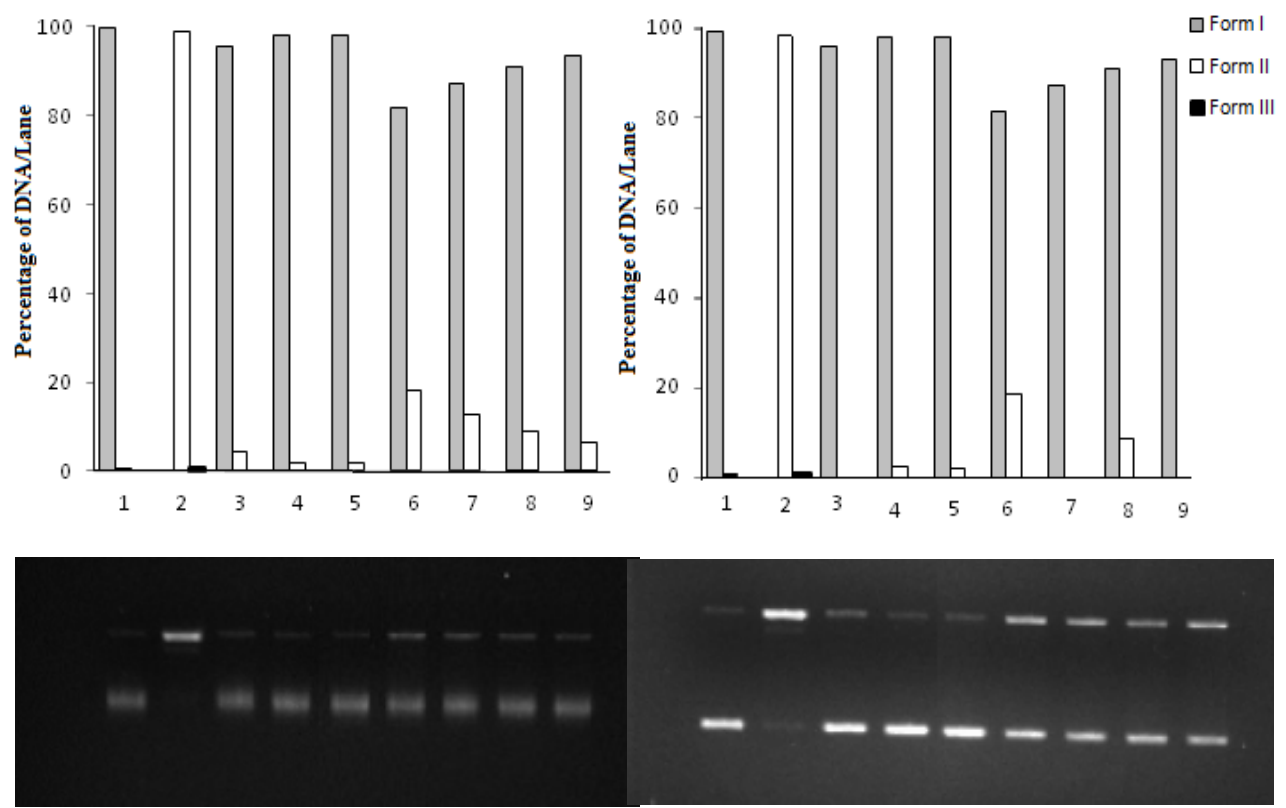

Fig. 3: (A) The quantified band intensity for the sc-DNA (form I), oc-DNA (form II) and lin-DNA (form III). (B) Electrophoretic pattern of pBluescript M13+DNA after UV-photolysis of $\mathrm{H}_{2} \mathrm{O}_{2}$ in the presence or absence of Rubus fruticosus (RFE) and Zizyphus vulgaris (ZVE) extract. Lane 1: control DNA; Lane 2: DNA+ $\mathrm{H}_{2} \mathrm{O}_{2}(2.5 \mathrm{mmol})+\mathrm{UV}$; Lane 3: DNA+UV; Lane 4: DNA+ $\mathrm{H}_{2} \mathrm{O}_{2}(2.5 \mathrm{mmol})$; Lane 5:

DNA+extract+UV; Lane 6: DNA+extract $(100 \mu \mathrm{g} / \mathrm{ml})+\mathrm{H}_{2} \mathrm{O}_{2}(2.5 \mathrm{mmol})+\mathrm{UV}$; Lane 7: DNA+extract $(250 \mu \mathrm{g} / \mathrm{ml})+\mathrm{H}_{2} \mathrm{O}_{2}(2.5 \mathrm{mmol})+\mathrm{UV}$; Lane 8: DNA+extract $(350 \mu \mathrm{g} / \mathrm{ml})+\mathrm{H}_{2} \mathrm{O}_{2}(2.5 \mathrm{mmol})+\mathrm{UV}$; Lane 9: DNA+extract $(500 \mu \mathrm{g} / \mathrm{ml})+\mathrm{H}_{2} \mathrm{O}_{2}(2.5 \mathrm{mmol})+\mathrm{UV}$
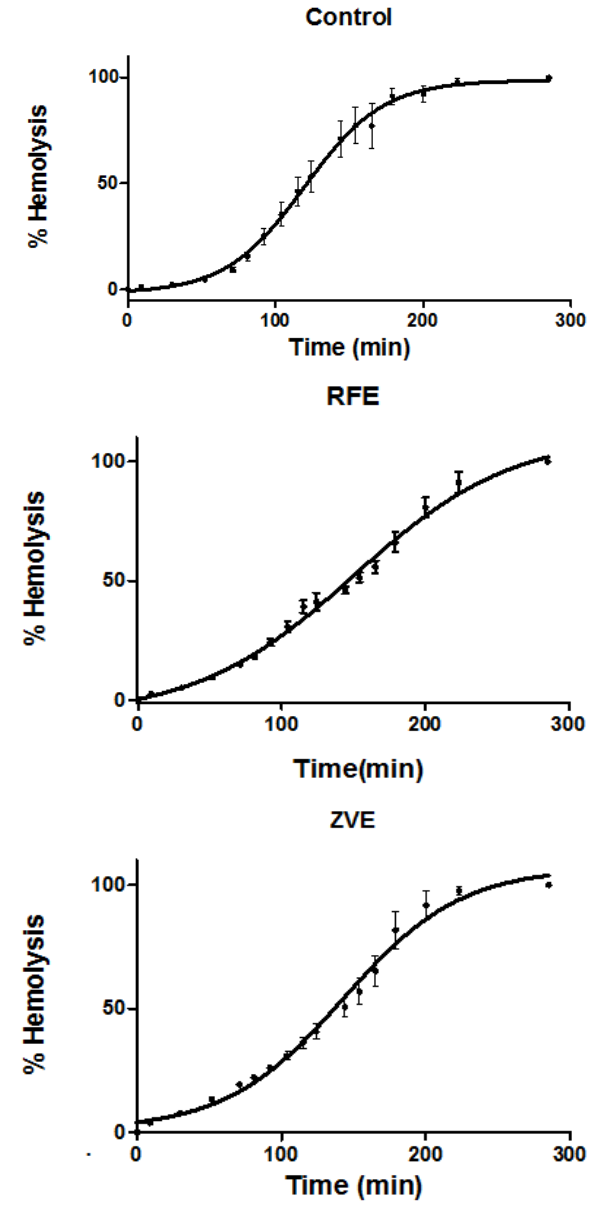

Fig. 4: Kinetics of the red blood cells hemolysis. Mice were given orally $200 \mathrm{mg} / \mathrm{kg}$ of Rubus fruticosus extract (RFE) and Zizyphus vulgaris extract (ZVE) extracts: The control group (control) received the same volume of vehicle. The values are means $\pm \operatorname{SEM}(n=6)$

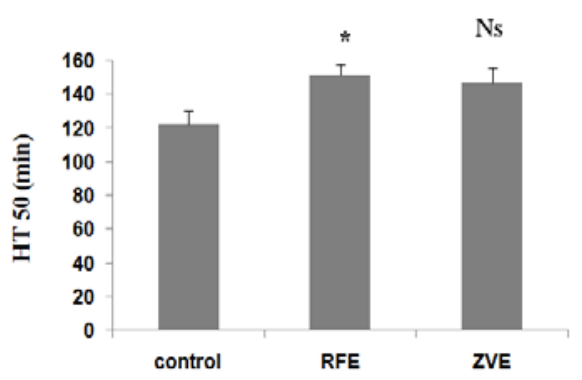

Fig. 5: Half-Hemolysis Time (HT50) for different groups. Values are expressed as means \pm SEM, ${ }^{*} P<0.05$. Ns: not significant versus the control

Indeed, the blood cell-like erythrocyte contains high concentrations of polyunsaturated fatty acids, molecular oxygen, and ferrous ions and is believed to be highly vulnerable to oxygen radical formation Erythrocytes are highly susceptible to oxidation; therefore erythrocytes are a suitable cellular model for investigation of the oxidative damage in biomembranes. Oxidant damage of cell films, which may be induced by TBH, can cause erythrocyte hemolysis [28].

The effectiveness of Rubus fruticosus extract in the increasing of HT50 could be attributed to it high phenolic and flavonoids contents. Dai et al. [29] have previously reported that flavonols and their glycosides are effective antioxidants protecting human red blood cells from free radical-induced oxidative hemolysis. The protective effect of flavonoids can be linked to their binding to the plasma membrane and their ability to penetrate lipid bilayers [30]. In addition, these results showed that the anti-hemolysis effect could be linked not only to the polyphenols and flavonoids contents of the extract but also to the chemical structure of these compounds. It was demonstrated that binding of flavonoids to the red blood cell membranes significantly inhibits lipid peroxidation, and at the same time enhances their integrity against lysis [31].

\section{Croton oil-induced ear edema in mice}

Croton oil-induced inflammation is a model for evaluation of drugs and extracts against acute inflammation. Severe vasodilatation, edematous changes of skin and inflammatory cell infiltration which are typical signs of acute inflammation are observed after topical 
application of croton oil [32]. Therefore croton oil offers a model for the exudative type of inflammation [3].

The obtained results (fig. 6) showed that the topical application of 2 $\mathrm{mg} / \mathrm{ear}$ of Rubus fruticosus and Zizyphus vulgaris extracts inhibited significantly $(P \leq 0.001)$ the croton oil-induced ear edema.

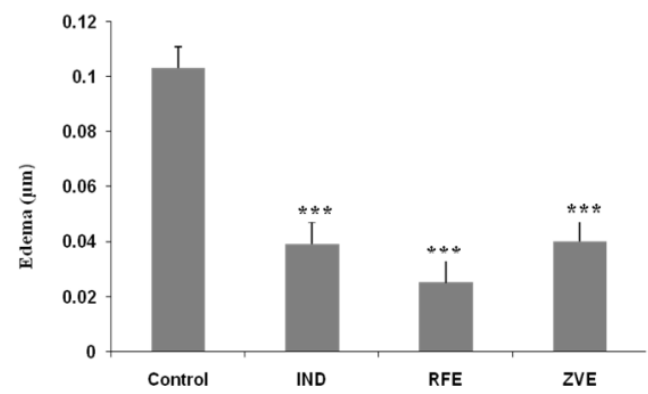

Fig. 6: Effect of Rubus fruticosus and Zizyphus vulgaris extracts on croton oil-induced ear edema. Mice were treated by topical application of $0.5 \mathrm{mg} / \mathrm{kg}$ of indomethacin (IND), $2 \mathrm{mg} / \mathrm{kg}$ of Rubus fruticosus extract (RFE), and Zizyphus vulgaris extract (ZVE). The control group received $0.2 \mathrm{ml}$ of normal saline solution (Control). Values are expressed as means \pm SEM $(\mathrm{n}=-6),{ }^{* * *} P<0.001$

The inhibition was $75.72 \%$ for Rubus fruticosus extract and $64.24 \%$ for Zizyphus vulgaris extract. These inhibitions were better than that obtained with indomethacin $(62.24 \%)$, used as the standard antiinflammatory agent. The topical anti-inflammatory effect of Rubus fruticosis and Zizyphus vulgaris extract may suggest that they have a lipophilic character, which enabled them to cross the skin barrier and exert antiphlogistic action [33].

In fact, Croton oil contains 12-o-tetracanoilphorbol-13-acetate (TPA) and other phorbol esters as main irritant agents. TPA is able to activate protein kinase $\mathrm{C}$ (PKC), which activates other enzymatic cascades in turn, such as mitogen-activated protein kinases (MAPK) and phospholipase A2 (PLA2), leading to the release of platelet activation factor (PAF) and arachidonic acid. This cascade of events stimulates vascular permeability, vasodilation, polymorphonuclear leukocytes migration, the release of histamine and serotonin and moderate synthesis of inflammatory eicosanoids by cyclooxygenase (COX) and 5-lipoxygenase (5-LOX) enzymes [34]. The antiinflammatory activity of the studied extract is probably attributed to COX and 5-LOX inhibitors, leukotriene B4 (LTB4) antagonists.

According to Saraiva et al. [35], plant extracts could produce their antioedematogenic effect by inhibiting the synthesis of eicosanoids and cytokines, in which $\mathrm{PGE}_{2}$ and TNF- $\alpha$ would be the main oedematogenic mediators.

The high anti-inflammatory activity of Rubus fruticosus extract is probably attributed to it high phenolic and flavonoid content Scutellarin is the major component. Identified in Rubus fruticosus extracts Studies have shown that Scutellarin exerts antiinflammatory action in several animal models]. In addition, it can inhibit lipopolysaccharide (LPS)-induced production of proinflammatory mediators such as NO, TNF- $\alpha$, IL-1 $1 \beta$ and ROS in rat primary microglia or BV-2 mouse microglial cell line [36]. It decreases the number of activated microglia and reduces the expression of Toll-like receptor 4 (TLR4), nuclear factor kappa B (NF-KB) p65 and inflammatory mediators [37].

Moreover, other flavonoids, such as quercetin and kaempferol, have demonstrated significant anti-inflammatory activity, which is attributed to the inhibition of PLA 2, COX and LOX enzymes and the inhibition of nitric oxide (NO) by modulating the inducible nitricoxide synthase (iNOS) enzyme [38].

\section{Acetic acid-induced vascular permeability in mice}

Chemical induced vascular permeability (acetic acid) causes an immediate stained reaction that is prolonged over $24 \mathrm{~h}$ [39]. As can be seen in (fig. 7), the amount of dye passed across the vessel in the control group was $55.94 \mu \mathrm{g} / \mathrm{ml}$. The treatment with Rubus fruticosus extract $(400 \mathrm{mg} / \mathrm{kg}$ ) significantly reduced the dye leakage to 37.16 $\mu \mathrm{g} / \mathrm{ml}$ (inhibition 33.57\%). However, a small reduction $41.67 \mu \mathrm{g} / \mathrm{ml}$ of the dye leakage was observed in the treatment with $400 \mathrm{mg} / \mathrm{ml}$ of Zizyphus vulgaris extract). This inhibition (25.51\%) was not significant. Indomethacin $(50 \mathrm{mg} / \mathrm{kg})$, as a standard drug strongly reduced the dye leakage to $31,40 \mu \mathrm{g} / \mathrm{ml}$ (inhibition $43,86 \%$ ).

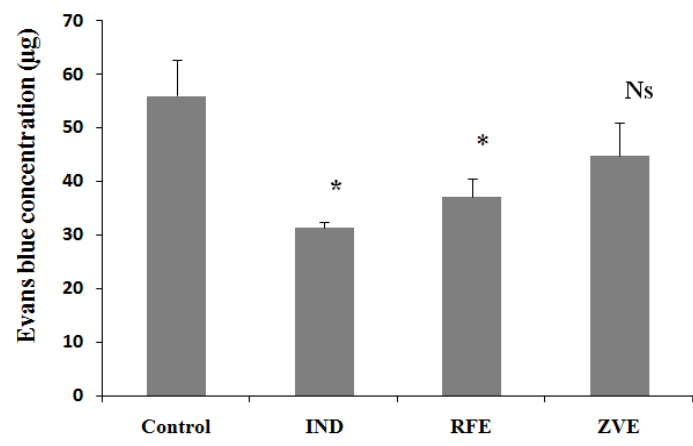

Fig. 7: Effect of Rubus fruticosus and Zizyphus vulgaris extracts on acetic acid-induced. Vascular permeability. Mice were given orally $400 \mathrm{mg} / \mathrm{kg}$ of Rubus fruticosis extract (RFE), Zizyphus vulgaris extract (ZVE) and $50 \mathrm{mg} / \mathrm{kg}$ of indomethacin (IND)

Control group (Control) received $0.2 \mathrm{ml}$ of normal saline solution. Values are expressed as means $\pm S E M,{ }^{*} P<0.05$. Ns: not significant versus the control

The inflammatory response is a physiological characteristic of vascularized tissues. The main features of acute inflammation are vasodilatation, the exudation of plasma, increase of vascular permeability and leukocyte migration into the site of inflammation [40]. Increased vascular permeability occurs as a result of contraction and separation of endothelial cells at their boundaries to expose the basement membrane, which is freely permeable to plasma proteins and fluid [41]

Phlogistic agents increase vascular permeability at various times after injury in inflammation condition. Acetic acid can cause the increase of chemical mediators such as prostaglandin E2 (PGE2), histamine and serotonin in peritoneal fluids, leading to the increase in vascular permeability [42].

The positive effect of Rubus fruticosis and Zizyphus vulgaris extracts suggest that they exert an anti-acute inflammatory action by inhibiting the inflammatory mediators.

\section{CONCLUSION}

The results of this study showed that Rubus fruticosus and Zizyphus vulgaris possess significant anti-inflammatory and antioxidant activities in vivo and in-vitro, establishing the ethnopharmacological basis for the use of these plants in traditional medicine. However, more studies are required for the isolation and characterization of the active principles responsible for these activities.

\section{ACKNOWLEDGMENT}

This work was supported by the Algerian Ministry of Higher Education and Scientific Research (MERS).

\section{CONFLICT OF INTERESTS}

\section{Declared none}

\section{REFERENCES}

1. Hyun TK, Kim HC, Ko YJ, Kim JS. Antioxidant, $\alpha$-glucosidase inhibitory and anti-inflammatory effects of aerial parts extract from Korean crowberry (Empetrum nigrum var. japonicum). Saudi J Biol Sci 2016;23:181-8.

2. Siroka Z, Svobodova Z. The toxicity and adverse effects of selected drugs in animals. Pol J Vet Sci 2013;16:181-91. 
3. Nwaehujor CO, Ezeja MI, Udeh NE, Okoye DN, Udegbunam RI. Anti-inflammatory and anti-oxidant activities of Mallotus oppositifolius (Geisel) methanol leaf extract. Arabian J Chem 2014; 7:805-10.

4. Tukun ABN, Shaheen CP, Mohiduzzaman M, Islam S, Begum M. Antioxidant capacity and total phenolic contents in hydrophilic extracts of selected Bangladeshi medicinal plants. Asian Pac J Trop Med 2014;7 Suppl 1:568-73.

5. Boullard B. Plante médicinale du monde: croyances et réalités. De Boeck Secundair. France; 2001.

6. Bruneton J. Pharmacognosie, phytochimie, plantes médicinales (4eme ed.) Lavoisier France; 2009.

7. Li HB, Cheng KW, Wong CC, Fan KW, Chen F, Jiang Y. Evaluation of antioxidant capacity and total phenolic content of different fractions of selected microalgae. Food Chem 2007;102:771-6.

8. Bahorun T, Gressier B, Trotin F, Brunete C, Dine T, Vasseur J, et al. Oxygen species scavenging activity of phenolic extracts from hawthorn fresh plant organs and pharmaceutical preparations. Drug Res 1996;46:1086-9.

9. Abay G, Altun M, Kolda S, Tüfekçi AR, Demirtas I. Determination of antiproliferative activities of volatile contents and HPLC profiles of Dicranum scoparium (Dicranaceae, Bryophyta). Comb Chem High Throughput Screening 2015;18:1-11.

10. Saija A, Tomaino A, Lo Cascio R, Rapisarda P, Dederen JC. In vitro antioxidant activity and in vivo photoprotective effect of red orange extract. Int J Cosmet Sci 1998;20:331-42.

11. Re R, Pellegrini N, Proteggente A, Pannala A, Yang M, RiceEvans C. Antioxidant activity applying an improved ABTS radical cation decolorization assay. Free Radical Biol Med 1999;26:1231-7.

12. Benzie IFF, Strain JJ. The ferric reducing ability of plasma (FRAP) as a measure of "antioxidant power": the FRAP assay. Anal Biochem 1996;239:70-6.

13. Attaguile G, Russo A, Campisi F, Savoca F, Acquaviva R, Ragusa $\mathrm{N}$, et al. Antioxidant activity and protective effect on DNA cleavage of extracts from Cistus incanus L. and Cistus monspeliensis L. Cell Biol Toxicol 2000;16:83-90.

14. Girard A, Madani S, Boukortt F, Cherkaoui-Malki M, Belleville J, Prost J. Fructose-enriched diet modifies antioxidant status and lipid metabolism in spontaneously hypertensive rats. Nutrition 2006;22:758-66.

15. Manga HM, Brkic D, Marie DEP, Quetin-Leclercq J. In vivo antiinflammatory activity of Alchornea cordifolia (Schumach. and Thonn.) Müll. Arg. (Euphorbiaceae). J Ethnopharmacol 2004;92:209-14.

16. Kou J, Si M, Dai G, Lin Y, Zhu D. Antiinflammatory activity of Polygala japonica extract. Fitoterapia 2006;77:411-5.

17. Watson RR, Preedy VR, Zibadi S. Polyphenols in human health and disease. Academic Press in print of Elsevier; 2013.

18. Saani M, lawrence R. Evaluation of pigments as antioxidant and antibacterial agents from Beta vulgaris linn. Int J Curr Pharm Res 2016;8:77-81.

19. Javanovic SV, Steenken S, Tosic M, Marjanovic B, Simic MJ. Flavonoids as antioxidants. J Am Chem Soc 1994;116:4846-51.

20. Huang D, Ou B, Prior RL. The chemistry behind antioxidant capacity assays. J Agric Food Chem 2005;53:1841-56.

21. Tirzitis G, Bartosz G. Determination of antiradical and antioxidant activity: basic principles and new insights. Acta Biochim Pol 2010;57:139-42.

22. Siddhuraju $P$, Becker $K$. The antioxidant and free radical scavenging activities of processed cowpea (Vigna unguiculata (L.) Walp.) seed extracts. Food Chem 2006;94:550-7.

23. Fidrianny I, Harnovi M, Insanu M. Correlation evaluation of antioxidant activities from various extracts of sweet orange peels using DPPH, FRAP assays and correlation with phenolic, flavonoid, carotenoid content. Asian J Pharm Clin Res 2014;7:186-90.

24. Yasmeen S, Gupta P. In vitro demonstration of Dalbergia sissoo (Indian rosewood) methanolic extracts as potential agents for sunscreening and DNA nick prevention. Int J Pharm Pharm Sci 2016;8:175-81.

25. Lobo V, Patil A, Phatak A, Chandra N. Free radicals, antioxidants and functional foods: Impact on human health. RE. Pharmacogn Rev 2010;4:118-26.
26. Villamena FA. Molecular basis of oxidative stress: chemistry, mechanisms, and disease pathogenesis. John Wiley and Sons; 2013.

27. Losdat S, Helfenstein F, Gaude B, Richner H. Reproductive effort transiently reduces antioxidant capacity in a wild bird. Behav Ecol 2011;12:1218-26.

28. Sen S, De B, Devanna N, Chakraborty R. Total phenolic, total flavonoid content, and antioxidant capacity of the leaves of Meyna spinosa Roxb., an Indian medicinal plant. Chin J Nat Med 2013;11:149-57.

29. Dai F, Miao Q Zhou B, Yang L, Liu ZL. Protective effects of flavonols and their glycosides against free radical-induced oxidative hemolysis of red blood cells. Life Sci 2006;78:2488-93.

30. Alvarez-Suarez JM, Giampieri F, Gonzalez-Paramas AM, Damiani E, Astolfi P, Martinez-Sanchez G, et al. Phenolics from monofloral honeys protect human erythrocyte membranes against oxidative damage. Food Chem Toxicol 2012;50:1508-16.

31. Henneberg R, Otuki FM, Furman AEF, Hermann P, Nascimento AG, Leonart MSS. Protective effect of flavonoids against reactive oxygen species production in sickle cell anemia patients treated with hydroxyurea. Rev Bras Hematol Hemoter 2013;35:52-5.

32. Ighodaro I, Ching F, Aigbe E. Anti-inflammatory activity of aqueous fruit pulp extract of Hunteria umbellata $K$. Schum in acute and chronic inflammation. Acta Poloniae Pharm Drug Res 2010;67:81-5.

33. Asuzu IU, Sosa S, Della LR. The anti-inflammatory activity of Icacina trichantha tuber. Phytomedicine 1999;6:267-72.

34. Leite GO, Leite LHI, Sampaio RS, Araruna MKA, Rodriguesa FFG, Menezesa IRA, et al. Modulation of topical inflammation and visceral nociception by Vanillosmopsis arborea essential oil in mice. Biomed Preventive Nutr 2011;1:216-22.

35. Saraiva RA, Araruna MK, Oliveira RC, Menezes KD, Leite GO, Kerntopf MR, et al. Topical anti-inflammatory effect of Caryocar coriaceumwittm. (Caryocaraceae) fruit pulp fixed oil on mice ear edema induced by different irritant agents. J Ethnopharmacol 2011;136:504-10.

36. Wang CJ, Wang JM, Lin WL, Chu CY, Chou FP, Tseng TH. Protective effect of Hibiscus anthocyanins against tert-butyl hydroperoxide-induced hepatic toxicity in rats. Food Chem Toxicol 2000;38:411-6.

37. Lucarini R, Tozatti MG, Silva MLA, Gimenez VMM, Pauletti PM, Groppo M, et al. Antibacterial and anti-inflammatory activities of an extract, fractions, and compounds isolated from Gochnatia pulchra aerial parts. Braz J Med Biol Res 2015;48:822-30.

38. Peters CA, Sgrott RAG, Peters RR, Moterle D, Madeir F, Emer $\mathrm{AA}$, et al. Production of Wilbrandia ebracteata extract standardised in flavonoids and dihydrocurcubitacin and assessment of its topical anti-inflammatory activity. Indian Crops Prod 2015;69:123-8.

39. Handoussa H, Hanafi R, Eddiasty I, El-Gendy MC, Khatib A, Linscheid M, et al. Anti-inflammatory and cytotoxic activities of dietary phenolics isolated from Corchorus olitorius and Vitis vinifera $f$. J Funct Foods 2013;5:1204-16.

40. Okoli CO, Akah PA, Nwafor SV, Anisiobi AI, Ibegbunam IN. Erojikwe 0. Anti-inflammatory and anti-nociceptive activities of Sipunculus nudus L. extract. J Ethnopharmacol 2007;109:219-25.

41. Kumar T, Jain V. Antinociceptive and anti-inflammatory activities of bridelia retusa methanol fruit extract in experimental animals. Sci World J 2014:12. http:// dx.doi.org/10.1155/2014/890151.

42. Zhang CX, Dai ZR, Cai QX. Anti-inflammatory and antinociceptive activities of Sipunculus nudus $L$. extract. J Ethnopharmacol 2011;137:1177-82.

\section{How to cite this article}

- Asma Meziti, Hamama Bouriche, Meziti Hichem, Seoussen Kada, Abderrahmane Senator, Ibrahim Dimertas. Antioxidant and anti-inflammatory activities of Rubus fruticosus and Zizyphus vulgaris methanol extracts. Int J Pharm Pharm Sci 2017;9(2):69-76. 